\title{
Original Research Article: Qualitative Research
}

\section{PSYCHOSOCIAL SUPPORT IN SELF-ACTUALIZING MAYER ROKITANSKY KUSTER HAUSER SYNDROME WOMEN}

\section{Gardha Rias Arsy ${ }^{1 *}$, Retty Ratnawati ${ }^{2}$}

${ }^{1}$ Mental Health Department, Nursing Program, STIKES Cendekia Utama Kudus.

2 Physiology Department, Faculty of Medicine \& Master Degree Program of Women Studies, Brawijaya University

\section{*Correspondence:}

Gardha Rias Arsy

Mental Health Department, Nursing Program, STIKES Cendekia Utama Kudus.

Jln. Lingkar Raya Kudus-Pati Km. 05 Jepang, Kec. Mejobo, Kab. Kudus, Jawa Tengah 59381

Email: gardarias051@gmail.com

\section{Article Info:}

Received: October 6, 2020

Revised: January 24, 2021

March 2, 2021

Accepted: March 12, 2021

DOI:

https://doi.org/10.36720/nhjk.v10i1.211

\begin{abstract}
Background: Self-concept is an individual's mode to completely see his personality, dealing with intelligence, emotion, spirituality, physical form, or social form. It provides continuity, consistency, and completeness for an individual. An individual with excellent self-concept could maintain their feeling of stability and positive behaviors directed for himself or other people. From the data of the MRKH community, thirty-three people were suffering MRKH in Indonesia.

Objectives: This research explored the self-concept experiences of women with Mayer Rokitansky Kuster Hauser syndrome.

Methods: This research is qualitative research with a phenomenological approach Interpretation. The data were collected from an in-depth interview with a structured design for seven participants.

Results: Such reproduction organ problems influence their life qualities because they think that a perfect woman's identity is to have a normal reproduction organ. This problem also influences their psychologies and have psychological and emotional traumas as well as self-concept changes. However, they tried to endure it and actualize themselves because they obtained support from their families and the MRKH community.

Conclusion: The states suffered by women with reproduction system problems influenced their psychological stabilities. The participants' medical teams should collaborate with psychiatrists and psychologists to foster a positive self-concept of the participants. Psychological counseling could improve their self-confidence and foster positive self-concepts.
\end{abstract}

Keywords: Psychosocial Supports, Self-Actualization, Mayer Rokitansky Kuster Hauser Syndrome.
(C) 2021 The Authors. Nurse and Health: Jurnal Keperawatan Published by Institute for Research and Community Service-

Health Polytechnic of Kerta Cendekia, Sidoarjo

This is an Open Access Article distributed under the terms of the Creative Commons Attribution-NonCommercial 4.0 (CC

BY-NC 4.0), which allows others to remix, tweak, and build upon the work non-commercially as long as the original work is properly cited. The new creations are not necessarily licensed under the identical terms.
E-ISSN

2623-2448

P-ISSN

2088-9909

\section{INTRODUCTION}

Mayer Rokitansky Kuster Hauser Syndrome, MRKH, is a mature female congenital abnormality that makes her cannot grow her fallopian tube, vagina, and uterus normally (Ismail et al., 2007). This condition is noticeable when a woman gets into her adolescent period or before getting menstruation (primary amenorrhea). It is a rare syndrome and occurs only one in 5.000 female birth rates all around the world. The conditions such as primary amenorrhea, sexual participation problem, and giving birth become a burden for these women. Such reproduction organ problems influence their life qualities because they think that a perfect woman's 
identity is to have a normal reproduction organ. This problem also influences their psychologies and have psychological and emotional traumas as well as self-concept changes.

\section{METHODS}

Study Design

This research is qualitative research with a phenomenological approach Interpretation.

\section{Setting}

This research was conducted in Regional Hospital. Dr. Loekmonohadi, Kudus, from January - February 2019.

\section{Research Subject}

The participants were women suffering from Mayer Rokitansky Kuster Hauser Syndrome. They were grouped into two categories. The first one consisted of those who ever checked themselves in the hospital. In contrast, the second category consisted of women that did not check themselves in the hospital but lived in Pati residency. The sample selection used a purposive sampling technique based on the applied criteria by the researchers. The criteria consisted of:

1. Women suffering Mayer Rokitansky Kuster Hauser Type 1.

2. Living in Kudus

3. Indonesian people

4. Voluntarily willing to be the participants

5. Willing to be interviewed during the research process.

The data collection procedure is a method used by researchers in the process of collecting research data. This procedure is carried out by using an in-depth interview technique using a semi-structured question guide, field notes or field notes with the aim of seeing the participant's non-verbal response and the situation during the interview process. The data analysis process in qualitative research is carried out continuously and interactively until it is complete, and reaches saturated data. This qualitative research uses Interpretative Phenomenological Analysis (IPA).

\section{Data Collection}

This research uses qualitative research using an interpretive phenomenology approach. This study aims to understand the phenomena that occur and are experienced by participants through a thorough and detailed research process including: what happened, how it happened and why it happened. In qualitative research, there is a process of communication and interaction between researchers and participants in depth.

The researchers took the data and information about the participants by visiting several midwives in Kudus' villages. On the other hand, the researchers also submitted the research proposal to Regional Hospital dr. Loekmonohadi after receiving permission from Kudus national and unitary political institution.

It was also important to get permission from The chairman of the Training and Education division of the hospital. After that, the researchers looked for documents in the Gynecology and medical record room of the hospital. The researchers discussed with the midwives to select the appropriate participants based on the inclusion criteria.

\section{Data Analysis}

The data analysis process in qualitative research is carried out continuously and interactively until it is complete, and reaches saturated data. This qualitative research uses data analysis that has been proposed by Smith, et al., (2009), namely Interpretative Phenomenological Analysis (IPA). Using science in analyzing data aims to be able to understand an event from the perspective of the participants. Understanding in this state has two meanings, namely understanding the interpretation in empathy and identifying, as well as the second meaning that understands in the process of interpreting. Interpretative Phenomenological Analysis emphasizes the form of meaning for both researchers and participants so that their thoughts can be used as a central analysis (Smith et al., 2009)

The stages of implementation in the Interpretative Phenomenological Analysis 
include: 1) Reading and re-reading; 2) Initial noting; 3) Developing Emergent themes; 4) Searching for connections across emergent themes; 5) Moving the next cases; 6) Looking for patterns across cases; 7) Taking Interpretations to deeper levels (Smith et al., 2009).

\section{Trustworthiness}

The stages of implementation in the Interpretative Phenomenological Analysis include: 1) Reading and re-reading; 2) Initial noting; 3) Developing Emergent themes; 4) Searching for connections across emergent themes; 5) Moving the next cases; 6) Looking for patterns across cases; and 7) Taking Interpretations to deeper levels.

\section{Ethical considerations}

This study has passed the ethical test held at the Faculty of Medicine, Brawijaya University with number 350/EC/KEPKS2/12/2018.

\section{RESULTS}

The major theme found in this research was a spirit to work. Although the women had a special status, they still executed the roles of women. This theme consisted of two subthemes: intention to have a better future and independently execute the women's roles. Here are the explanations of the sub-themes:

\section{Intention to have a better future}

This theme is a sub-theme from a theme of spirit to work and execute the roles as women with all of their specific statuses. This subtheme describes the patients' intentions for a better future. Here are the excerpts.

“..I focus on my study and help my parents.. $\underline{I}$ have a dream to make them proud although I cannot give a birth and bring them grandchildren.. " $(\boldsymbol{P} 7)$.

"That is the reason I want to continue my study and work.. I want to spend my time studying and worshiping. I also want to get my master degree from overseas when it is necessary.." (P2).

The statements showed their intentions to make their parents proud of them although they had specific conditions, being unable to give birth.

\section{Becoming an Independent Woman}

This sub-theme described that they wanted to act their roles independently, although they had specific conditions, having weaknesses in their reproduction system. Here are the excerpts.

\section{"That is the reason I want to continue my study and work. I want to spend my time studying and worshiping. I also want to get my master degree from overseas when it is necessary.." (P2). \\ "Even with my condition, I want to keep working I also have good position in my career.."(P4).}

“..After being divorced, I row my life alone with my adopted child because my ex husband left us. I am feeling grateful of being capable to work and take my child to school.." (P3)

The statements showed they had eager to live, worship, and study for their futures and careers. They empowered themselves, executed their roles as women, and did not get slumped due to their conditions.

\section{DISCUSSION}

The psychological support received by the participants become the theme of this research. The families or MRKH community represented the meaning of the participants with their surrounding supports. These encouraged them to accept and motivate themselves to row their lives. This theme also had two sub-themes: MRKH community support and psychological support from the families. Here are the explanations of the sub-themes: 


\section{MRKH community supports}

Patients or participants with special conditions need to get support not only in the form of material but also in dire need of psychological support. Psychological support has a major impact on self-acceptance and increases in self-confidence in MRKH participants. They feel that someone still cares about their situation, feels needed, and is still loved. Psychological or social support is not only from family, but can be accepted through the surrounding community, peers, and certain communities.

Social support can be interpreted as support that comes from the surrounding environment or a simpler scope or broad scope which will later provide physical comfort and psychological calm. Tentama (2014) describes social support which has an important role in the human life system, especially for those who experience post-traumatic stress disorder (PTSD). Individuals who are experiencing PTSD really need attention, support from loved and trusted people around them to help in overcoming or going through the stress disorder that is being experienced (Asfiah, 2011).

This support was also felt by the MRKH participants where they felt confident again, strengthened their mentality to return to struggle to recover and treat their illnesses. The existence of social support provides a forum for MRKH women to share stories and train themselves to socialize with their environment. Although in Indonesia it is still small in scope.

In developed countries like America, the MRKH incident has become a special concern by the government. They provide counseling assistance to every woman who is positive for MRKH. Providing counseling can reduce the client's stress level. They can comfortably tell and convey what they feel with a variety of methods and media.

The statements showed that the participants accepted themselves after having supports from the families of their husbands.

Women with reproduction system disorder are different from normal women. It makes them cannot execute their roles as a wife since they cannot normally have intercourses and cannot pregnant. However, on the other hand, they could still execute their other roles independently, such as career, study, and worship. They wanted a better future for them.

Their feelings and conditions were similar to what had been found by Machdan (2012). He found that people with disabilities, such as after getting an accident, still had optimism and accepted themselves positively. People who could accept themselves would be better in terms of interaction and adjusting themselves to the surrounding environment. They also could create a harmonious family relationship. Of course, they would undergo a lot of challenging mental processes before being able to accept themselves positively. By the time they could define their lives better.

Senra (2011) states that the meaning of life experienced by a human is unique and different from one to another. Each condition they engaged would have different challenges for their lives. Thus, these could bring the meaning of life for those individuals.

Confident MRKH women could be defined as their lives more positive. Positive interaction among individuals in their surrounding environment could foster their self-confidence. According to Suyana (2008), a confident individual will feel safe, responsible, optimistic, and believe in their capabilities. Therefore, self-confidence is important for every individual, especially women with MRKH. It helps them to adjust themselves to the environment and families.

Such individuals require psychological supports instead of material supports. This psychological support greatly influenced their self-acceptance and improved their confidence. They would feel that their surrounding people still cared, needed, and loved them. Psychological supports may be from families, surrounding people, peers, and a particular community.

Social support can be defined as supports from the surrounding environment or simple and larger scoped spaces. It could provide physical and psychological conveniences. 
Tentama (2014) explains that social support has an important role in the human life system, moreover those with Post Traumatic Stress Disorder (PTSD). These individuals require attention, support from their beloved persons, and trust from surrounding people to overcome their stresses (Asfiah, 2011).

MRKH participants found that supports made them confident, strong, and eager to get fully recovered and cure their diseases. Social support becomes a mode for women with MRKH to share stories, train themselves, and socialize with the environment. Although it is still a small-sized community in Indonesia, it would be helpful.

In advanced countries, such as the United States of America, MRKH rates have gained special attention from the government. They provided counseling for every woman with positive MRKH so that it could relieve their stress levels. They could share what they felt conveniently through various methods and media.

\section{CONCLUSION}

The conclusion in this study is that the themes obtained from data analysis and research results are used to answer the existing specific objectives. The specific aim of exploring the view of the physical condition of women with major hauser syndrome has been answered by the theme of feeling physically handicapped and assuming "plague" is the cause of the disease.

Furthermore, the specific goal is to explore the psychological experiences of women with major hauser syndrome supported by the theme of accepting Allah SWT's provisions forcibly, needing time to calm down, and being trapped in unhealthy household conflicts. In addition to these themes, there are themes of fear of not being able to live out their nature as a woman, covering up disgrace, and experiencing social relationship disorders. These have answered from the specific goal of exploring self-esteem in women with major hauser syndrome.
With the specific aim of exploring the role of self-acceptance in women with major rockdeep cluster hauser syndrome, the answer is based on the theme of being determined to actualize oneself despite experiencing "special circumstances". The next specific objective is to explore the support system in women with major Rokitansky cluster huaser syndrome, which is on the theme of getting psychological support. The next specific objective which aims to explore the hopes and challenges of women with major rokitansky kuster hauser syndrome has been answered with the theme of feeling inhibited for further treatment, and the desire to be healed and normal.

\section{SUGGESTIONS}

There will be a need for a qualitative study concerning mental-nursing cases. It is also important to investigate significant experiences from various perspectives. For example, the male's perspective, when he accepts his wife is suffering MRKH. It could be a meaningful description and provide different results from the female's perspective. Thus, the results could complement this research and previous research findings.

It is suggested to prioritize caring. Clients also need comprehensive review instead of only fulfilling the clients' necessities physically. It is also important to consider their psychological effects. The health team needs to foster a proper collaboration system and involves psychiatrists to provide counseling and supports for psychological cases, such as occurring with MRKH women.

Learners could use these research findings as additional learning materials and science enrichment to provide nursing care and mental nursing care for specific groups.

\section{ACKNOWLEDGMENT}

Thanks to all parties that assisted this research. 


\section{DECLARATION OF CONFLICTING INTEREST}

None.

\section{FUNDING}

Personal financial funding from the researcher.

\section{AUTHOR CONTRIBUTION}

Gardha Rias Arsy: Analyzing data, determining themes, arranging permits, and making discussions with related research.

Retty Ratnawati: Helping the verbatim process and Participate in In-depth interviews.

\section{ORCID}

Gardha Rias Arsy

https://orcid.org/0000-0001-5380-764X

\section{Retty Ratnawati}

https://orcid.org/0000-0002-0465-4090

\section{REFERENCES}

Bean, E., Mazur, T., \& Robinson, A. (2008). Mayer-Rokitansky-Küster-Hauser

Syndrome: Sexuality, Psychological Effects, and Quality of Life. Journal of Pediatric and Adolescent Gynecology, 22, 339-346.

Berger, A., Batzer, F., Lev-Toaff, A., \& BerryRoberts, C. (2013). Diagnostic Imaging Modalities for Müllerian Anomalies: The Case for a New Gold Standard. Journal of Minimally Invasive Gynecology, 21, 335345.

Bianchi, S., Frontino, G., Ciappina, N., Restelli, E., \& Fedele, L. (2011). Creation of a neovagina in Rokitansky syndrome: Comparison between two laparoscopic techniques. Fertility and Sterility, 95(3), 1098-1100.

Gupta, M., \& Kharb, V. (2012). MRKH Syndrome: Psychological Disturbances and Suicide. Journal of Indian Academic Forensic Medicine, 34(1), 86-88.

Healey, A. (2010). Embryology of the Female Reproductive Tract. Imaging of
Gynecological Disorders in Infants and Children Medical Radiology, 21-30.

Herlin, M., Højland, A., \& Petersen, M. (2014). Familial occurrence of MayerRokitanskyKüster-Hauser syndrome: A case report and review of the literature. American Journal of Medical Genetics Part A, 164A, 2276-2286.

Ledig, S., Schippert, C., Strick, R., Beckmann, M., Oppelt, P., \& Wieacker, P. (2011). Recurrent aberrations identified by arrayCGH in patients with MayerRokitanskyKüster-Hauser syndrome. Fertility and Sterility, 95(5), 1589-1594.

Moore, K., \& Persaud, T. (2008). The Urogenital System. In The Developing Human: Clinically Oriented Embryology (8th [ed.]. ed., pp. 242-283). Philadelphia, Pa.: Saunders.

Patnaik, S., Brazile, B., Dandolu, V., Ryan, P., \& Liao, J. (2014). Mayer- RokitanskyKüster-Hauser (MRKH) syndrome: A historical perspective. Gene, 555, 33-40.

Pizzo, A., Laganà, A., Sturlese, E., Retto, G., Retto, A., Dominici, R., \& Puzzolo, D. (2012). Mayer-Rokitansky-Kuster-Hauser Syndrome: Embryology, Genetics, and Clinical and Surgical Treatment. ISRN Obstetrics and Gynecology, 2013, 1-10.

Rall, K., Barresi, G., Walter, M., Poths, S., Haebig, K., Schaeferhoff, K., Brucker, S. (2011). A combination of transcriptome and methylation analyses reveals embryologically-relevant candidate genes in MRKH patients. Orphanet Journal of Rare Diseases, 6, 32-44.

Robbins, J., Broadwell, C., Chow, L., Parry, J., \& Sadowski, E. (2014). Müllerian duct anomalies: Embryological development, classification, and MRI assessment. Journal of Magnetic Resonance Imaging, 41, 1-12.

Sandbacka, M., Laivuori, H., Freitas, É, Halttunen, M., Jokimaa, V., MorinPapunen, L., Aittomäki, K. (2013). TBX6, LHX1, and copy number variations in the complex genetics of Müllerian aplasia. 
Orphanet Journal of Rare Diseases, 8, 125-138.

Sekido, R., \& Lovell-Badge, R. (2009). Sex determination and SRY: Down to a wink and a nudge? Trends in Genetics, 25(1), 19-29.

Cite this article as: Arsy, G. R., Ratnawati, R. (2021). Psychosocial support in self-actualizing mayer rokitansky kuster hauser syndrome women. Nurse and Health: Jurnal Keperawatan, 10 (1), 45-51. https://doi.org/10.36720/nhjk.v10i1.211 